\title{
Youth minimum wages and youth employment
}

\author{
Maria Marimpi ${ }^{1}$ and Pierre Koning $2,3,45^{*}$
}

\footnotetext{
* Correspondence: p.w.c.koning@vu. $\mathrm{nl}$

${ }^{2}$ Department of Economics, VU University Amsterdam, De Boelelaan 1105, P.O. BOX 80510, NL 1081 HV Amsterdam, The Netherlands ${ }^{3}$ Leiden University, Leiden, The Netherlands

Full list of author information is available at the end of the article
}

\begin{abstract}
This paper performs a cross-country level analysis on the impact of the level of specific youth minimum wages on the labor market performance of young individuals. We use information on the use and level of youth minimum wages, as compared to the level of adult minimum wages as well as to the median wage (i.e., the Kaitz index). We complement these data with variables on the employment, labor force participation, and unemployment rates of 5-year age interval categories - all derived from the official OECD database. We distinguish between countries without minimum wages, countries with uniform minimum wages for all age groups, and countries with separate youth and adult minimum wages. Our results indicate that the relative employment rates of young individuals below the age of 25-as compared to the older workers - in countries with youth minimum wages are close to those in countries without minimum wages at all. Turning to the smaller sample of countries with minimum wages, increases in the level of (youth) minimum wages exert a substantial negative impact on the employment rate for young individuals.
\end{abstract}

JEL Classification: J21, J23, J31

Keywords: Youth minimum wages, Employment, Labor supply, Cross-national studies

\section{Introduction}

One common finding in the empirical literature is that young individuals are relatively strongly affected by the imposition of minimum wages, both by raising their income level and by decreasing their employment-see, e.g., Clemens and Wither (2016), Kalenkoski (2016), Neumark and Wascher (2007), Neumark et al. (2014) and Laporsek (2013) for recent contributions. ${ }^{1}$ Uniform minimum wages may also reduce on-the-job-training opportunities and discourage younger individuals from entering the labor market. Particularly since the onset of the Great Recession, this delayed entry into the labor market may have reduced individuals' lifetime stream of earnings (Carcillo et al., 2015).

With this in mind, policymakers may consider the use of specific youth minimum wages instead of uniform minimum wages that are equal for all ages. Youth minimum wage rates are typically set as a fraction of the adult minimum wage, with systems ranging from single minimum wage rates for all young workers below a certain age (as in Greece, Ireland, Portugal) to step-wise functions of an individual's calendar age (as in

(c) The Author(s). 2018 Open Access This article is distributed under the terms of the Creative Commons Attribution 4.0 International License (http://creativecommons.org/licenses/by/4.0/), which permits unrestricted use, distribution, and reproduction in any medium, provided you give appropriate credit to the original author(s) and the source, provide a link to the Creative Commons license, and indicate if changes were made. 
the UK, Australia, and The Netherlands) (see Table 6 in the Appendix for details on the implementation of youth minimum wage systems).

Although there is abundant empirical work on the employment effects of general minimum wages on young individuals, studies on the specific effect of youth minimum wages on youth employment are scarce. So far, findings for single countries provide inconclusive evidence; they are largely dependent on the specific context and to identifying assumptions and usually only focus on the short-term impact of changes in youth minimum wages. Typically, this literature exploits reforms or discontinuities of systems in specific countries. For the UK, Dickens et al. (2010, 2014) and Fidrmuc and Tena (2013) use regression discontinuity designs to estimate the impact of a $20 \%$ increase of the minimum wage on the 22-year-olds. Dickens et al. find positive employment effects, whereas Fidrmuc and Tena find evidence of negative or no employment effects. For New Zealand, Hyslop and Stillman (2007) perform a difference-in-differences analysis to compare the employment results of young workers who experienced changes in their relative minimum wages (16-17- and 18-19-year-olds) with young adults whose minimum wage rates remained unaffected (20-25-year-olds). Their results indicate insignificant employment effects for both affected groups. Finally, Olssen (2011) studies the impact of a 10\% minimum wage increase on workers aged 15-21 in Australia. He finds no effect of the changes in youth rates on short-run youth employment.

This paper is the first to perform a cross-country level analysis that explicitly focuses on the impact of the level of specific youth minimum wages. As such, we add to the analyses of Neumark and Wascher (2004) and Dolton and Bondibene (2012), who exploit cross-country variation in general minimum wages of OECD countries to estimate employment on young and adult individuals. Both these studies find that the presence of youth minimum wages reduces the detrimental impact that general minimum wages may have on employment rates. In the current paper, we contribute to this line of research by investigating how the level of youth minimum wages-as compared to the adult minimum wage or the median wage-affects the employment rate, the labor force participation, and the unemployment rate of younger individuals. Contrasting to the earlier analyses, we thus exploit variation in the use and level of minimum wages across ages within countries.

For our analysis, we follow 30 OECD countries, out of which 21 have implemented minimum wages, between 2000 and 2014. Using information from governmental statistics and OECD publications, we are able to define the use and, if relevant, the level of youth minimum wages compared to uniform minimum wages and to the median wage. More specifically, we construct series of youth rates by recording the level of wage that is eligible at each age. We complement these data with data on the employment, labor force participation, and unemployment level of 5-year age interval categories-all derived from the official OECD database. Our focus is on cross-country differences in the age profiles of employment, labor force participation, and unemployment rates that can be explained by the use of uniform and youth minimum wages. By controlling for interacted country and year fixed effects, we effectively compare the relative labor market position of young individuals with the relative labor market position of young individuals in other countries. In doing so, the key assumption we need to make is that minimum wage settings are not correlated with other labor market institutions that determine labor market outcomes of young individuals. We therefore restrict our 
sample to young individuals below the age of 35; this setup corresponds to a regression discontinuity design wherein young individuals may face similar youth policies but are either located to the left or the right of the age cutoff-point that determines whether youth or adult minimum wages prevail.

To investigate the effect of minimum wages, we first compare the differences in the relative labor market performance of individuals below the age of 25 between the three country groups. In line with the analyses of Neumark and Wascher (2004) and Dolton and Bondibene (2012), we find the relative employment of young individuals below the age of 25-as compared to older individuals between the age of 25 and 35-in countries with youth minimum wages to be similar to the employment rates of their peers in countries without statutory minimum wages. However, employment rates are substantially lower for young individuals in countries that employ uniform minimum wages.

We next zoom into the sample of the 21 countries that set statutory minimum wages-either uniform or age-specific. Using fixed effects for all possible combinations of countries and years, we compare the relative labor market position of young individuals (vis-à-vis older ones) who are exposed to youth minimum wages with the relative labor market position of their peers that receive adult rates. We specify youth minimum wages as a fraction of both the adult minimum wage and/ or the median wage in a particular country. Following this strategy, the use of a specific youth minimum wage rate exerts a positive and statistically significant effect on the employment rate of young individuals for whom it applies. In particular, a 1 percentage point increase in the youth minimum wage as a fraction of the median wage-i.e., the "Kaitz index"-causes the employment rate of young individuals to decrease with 0.72 percentage points. We also find positive labor force participation effects of youth minimum wages, which suggests the mitigation of discouraged-worker effects that prevail with uniform minimum wages.

The remainder of this paper is organized as follows. Section 2 provides a description of the data sources and the construction of our variables. Section 3 explains the empirical strategy, whereas the estimations results and robustness analyses are discussed in Section 4. Finally, Section 5 concludes.

\section{Data}

We use data derived from databases and from OECD publications. Data on labor market outcomes, including the employment to population ratio, labor force participation, and unemployment rate, are acquired from the OECD Statistics Database. $^{2}$ These variables are measured as (unweighted) averages of 5-year age intervals for 30 OECD countries followed between 2000 and $2014 .^{3}$ We complement these data with information on the incidence and level of adult and youth minimum wages, as derived from OECD Employment Outlook reports of 1998 and 2015, Eurostat and governmental information sources. ${ }^{4}$

With these data, we compare country groups that are stratified with respect to the presence of statutory national minimum wages (or not) and the presence of youth minimum wages (or not). In effect, we have four country groups in our sample that may overlap in some cases: countries with statutory minimum wages (group 1), countries without statutory minimum wages (group 2), countries with specific minimum youth wages at some point in time (group 1A), and countries with uniform statutory 
minimum wages at some point in time (group 1B). For each country and year, we constructed the following variables:

i. A dummy value that indicates whether an age category is subject to youth minimum wages or not. This fraction is equal to one for the age categories that receive a youth minimum wage and zero across all age categories in countries without youth minimum wages as well as for the rest of the age categories for which the adult minimum wage applies in countries with youth minimum wages.

ii. The level of the youth minimum wage rates as a percentage of the adult minimum wage. This variable is used in our main analysis where we concentrate on the group of countries with national minimum wages; it is equal to 1 for the age categories that are eligible for an adult minimum wage. In countries with uniform minimum wages, all age categories are assigned with "1".

iii. The level of the (youth) minimum wage rate relative to the median wage-i.e., the Kaitz index. Again, this variable concerns the group of countries with legally binding minimum wages and is used in the main analysis. Where a youth minimum does not exist, this variable is equal to the uniform minimum-to-median wage.

As the labor market data we use are measured at the level of 5-year age intervals, we need to transform the above variables into 5-year age interval values as well. For this purpose, we assume equal relative weights of five consecutive years in an age interval. Thus, for intervals where we observe a change of the youth into the adult minimum wage at a particular age, we compute the weighted average of variable values before and after the minimum age for which the adult minimum applies. $^{6}$

Table 1 categorizes the countries into groups 1, 2, 1A, and 1B. In our sample, 21 out of 30 OECD countries had statutory minimum wages in the period under investigation (i.e., group 1). These include most of the European countries, as well as Canada, Australia, Japan, Korea, Turkey, and the USA. Group 2 includes countries without statutory minimum wages, namely the Nordic countries, Italy, Austria, and Switzerland. ${ }^{7}$ More relevant to our study is the lower part of Table 1, which concentrates solely on countries of group 1 and further categorizes them into those that employ lower youth rates (group 1A) and those that do not (group 1B). Two countries, Belgium and Greece, appear in both groups $1 \mathrm{~A}$ and $1 \mathrm{~B}$ at the same time, since they did not have specific youth minimum wages in the full time period under investigation. Belgium phased out specific youth wages during 2013-2015, whereas Greece introduced them in 2012.

Figure 1 reveals substantial variation in the level of minimum wages across countries in group 1 . The real average hourly minimum wage level for the period 2000-2014 was less than 3 US dollars in the Slovak Republic and Estonia, while it exceeded 10 US dollars in France, Australia, and Luxembourg. In this respect, it should be noted that taxes and other non-wage labor costs may significantly affect the net wage (or "take home pay") as well as the cost of labor for employers. It is estimated that the total tax burden from social contributions and other obligatory payments for OECD countries reaches nearly one third of gross minimum wage, on average, with the shares being almost equally paid by employers and workers (OECD, 2015). 
Table 1 Classification of countries on minimum wage systems (2000-2014)

\begin{tabular}{|c|c|c|c|}
\hline \multicolumn{2}{|c|}{$\begin{array}{l}\text { Group 1: Countries with statutory minimum } \\
\text { wages }\left(N_{1}=21\right)\end{array}$} & \multicolumn{2}{|c|}{$\begin{array}{l}\text { Group 2: Countries without statutory } \\
\text { minimum wages }\left(N_{2}=9\right)\end{array}$} \\
\hline Australia & Luxembourg & \multicolumn{2}{|c|}{ Austria } \\
\hline Belgium & Netherlands & \multicolumn{2}{|c|}{ Denmark } \\
\hline Canada & New Zealand & \multicolumn{2}{|c|}{ Finland } \\
\hline Czech Republic & Poland & \multicolumn{2}{|c|}{ Germany } \\
\hline Estonia & Portugal & \multicolumn{2}{|c|}{ Iceland } \\
\hline France & Slovak Republic & \multicolumn{2}{|c|}{ Italy } \\
\hline Greece & Spain & \multicolumn{2}{|c|}{ Norway } \\
\hline Hungary & Turkey & \multicolumn{2}{|c|}{ Sweden } \\
\hline Ireland & UK & \multicolumn{2}{|c|}{ Switzerland } \\
\hline Japan & USA* & & \\
\hline \multicolumn{4}{|l|}{ Korea } \\
\hline \multicolumn{4}{|c|}{ Classification of group 1 according to youth rates } \\
\hline \multicolumn{2}{|c|}{$\begin{array}{l}\text { Group 1A: Countries with minimum } \\
\text { wages and youth rates }\end{array}$} & \multicolumn{2}{|c|}{$\begin{array}{c}\text { Group 1B: Countries with uniform } \\
\text { minimum wages }\end{array}$} \\
\hline Australia & New Zealand & Belgium & Hungary \\
\hline Belgium & Portugal & Canada & Japan \\
\hline Greece & Slovak Republic & Czech Republic & Korea \\
\hline Ireland & Turkey & Estonia & Poland \\
\hline Luxembourg & UK & France & Spain \\
\hline Netherlands & & Greece & USA \\
\hline
\end{tabular}

*USA is considered in our data as a country without youth minimum wages, since the lower rates are associated with job tenure. When we include the USA in the data as a country with uniform minimum wages, our results are virtually identical.

Almost half of the OECD countries with a statutory minimum wage use specific minimum wages for young workers. Figure 2 illustrates the relative youth rate as a ratio of the adult rate and of the median wage at each age for workers aged 15 to 25, measured in 2014. In countries like Australia and the Netherlands, the

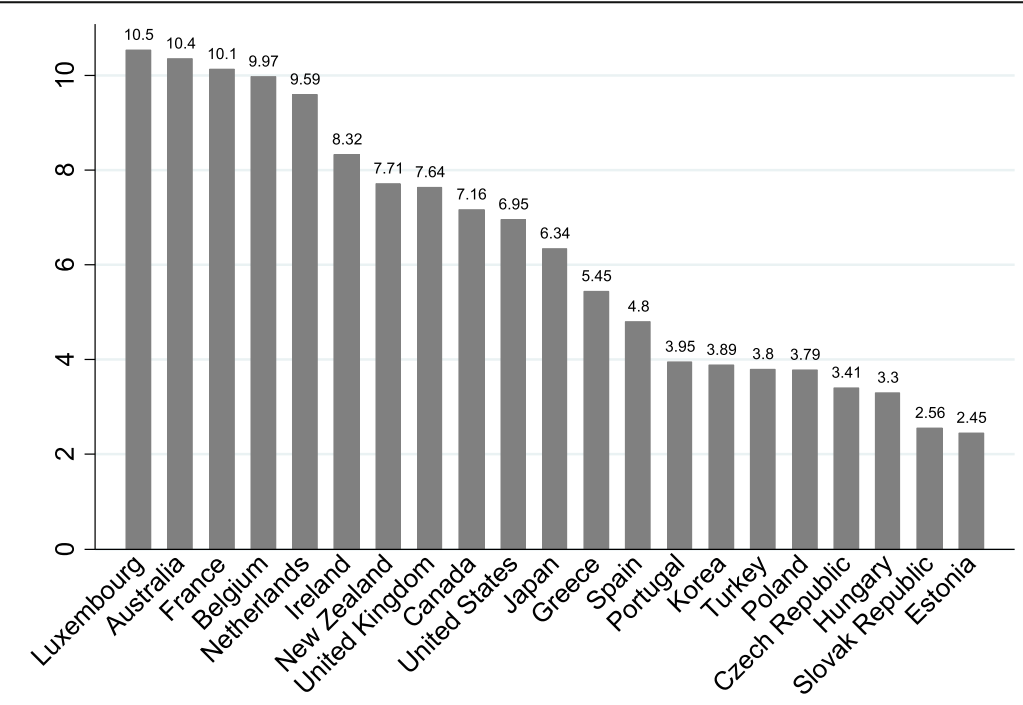

Fig. 1 Average hourly adult minimum wages, \$US 2014 PPP 


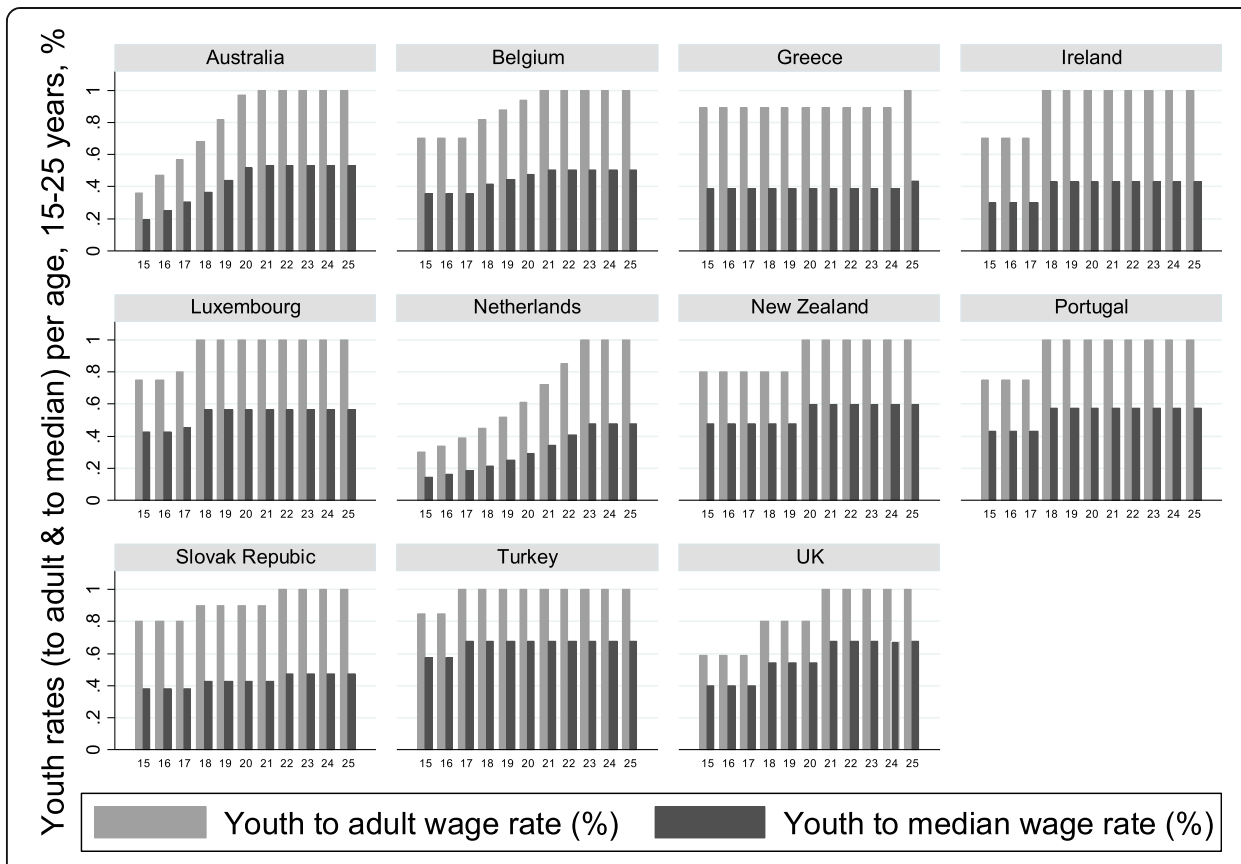

Fig. 2 Share of youth minimum wage rate to the adult minimum wage rate and to the median wage rate as a function of age, 15-25 years old (measured as shares; 2014)

minimum wage for young workers is specified as a step-wise increasing function of the worker's age. In particular, it starts at a very low age, usually at 15 and approximately at $30 \%$ of the adult wage while it gradually increases till the age of 23 . In contrast, a single subminimum for young workers exists in Greece, Ireland, and Portugal. In other countries, such as the UK or the Slovak Republic, the youth rate involves up to two youth rates for age groups of young workers for whom the adult minimum wage does not apply.

As a first eyeball test of minimum wage effects, Fig. 3 plots the employment rate per age category for our four country groups, averaged over all years in our sample. ${ }^{8}$ The upper panel of each graph compares the average outcomes in countries with statutory minimum wages (group 1) with those without statutory minimum wages (group 2); the lower panel of each graph compares the average outcomes for countries with youth minimum wages (group 1A) with those with uniform minimum wages (group 1B). Countries without minimum wages have higher employment rates than those with minimum wages. This is particularly true for individuals below the age of 25 . Interestingly, we also find marked differences between the employment outcomes of younger workers in countries with youth minimum wages and those with uniform minimum wages. Differences in employment rates between groups $1 \mathrm{~A}$ and $1 \mathrm{~B}$ are more prominent for younger ages than for older age groups, suggesting that youth minimum wage may have an impact on labor market outcomes.

\section{Model specification}

To estimate the effect of youth minimum wages on youth employment, we start with an exploratory investigation on the effect of uniform and youth minimum wages on young individuals' relative labor market outcomes below the age of 25 , as compared to 

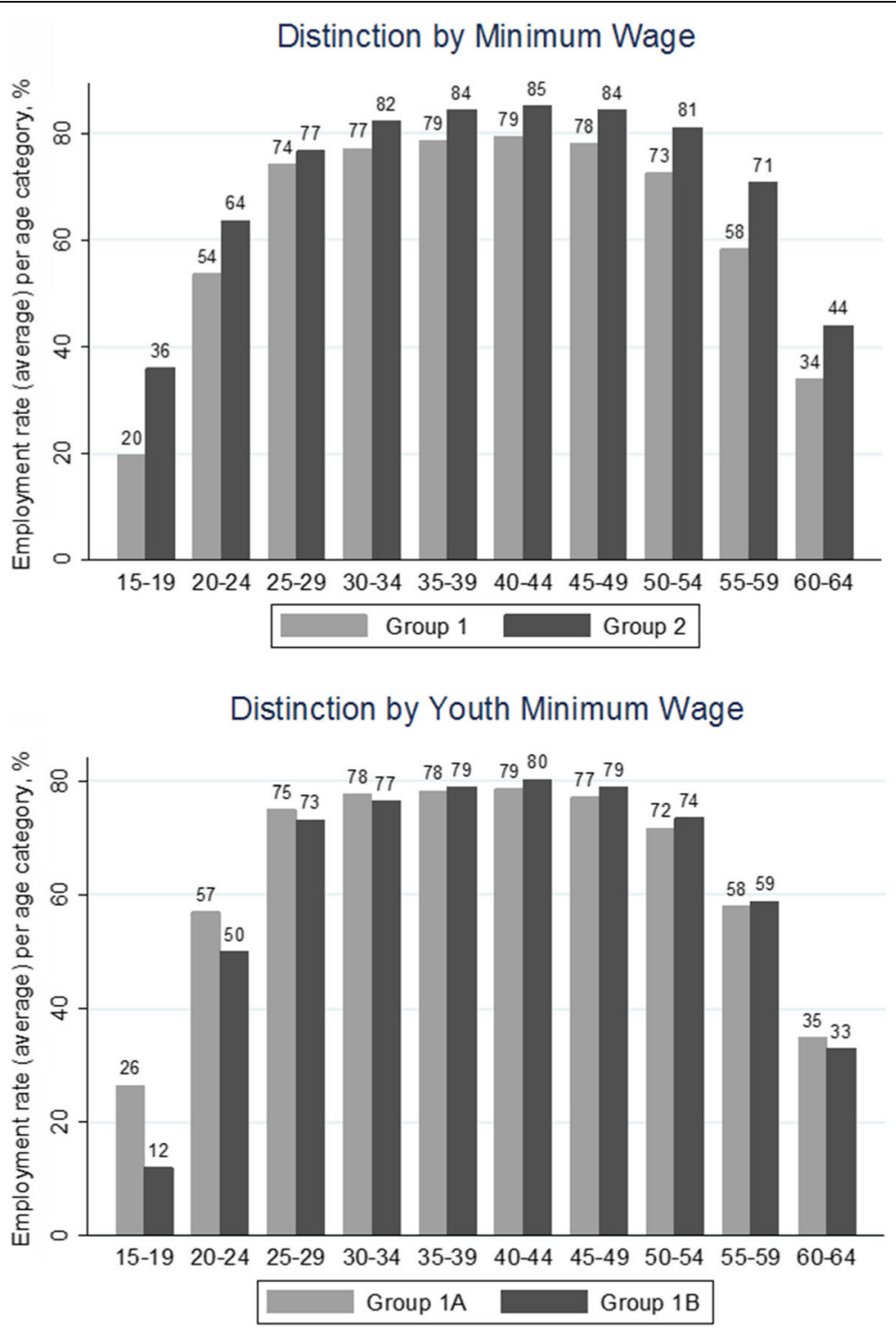

Fig. 3 Average employment rate per age category for countries with statutory minimum wages (group 1) and without statutory minimum wages (group 2) and for countries with youth wages (group 1A) and with uniform wages (group 1B)

those aged between 25 and 35. More specifically, we compare the relative employment rate, labor force participation rate, and the unemployment rate of individuals below the age of 25 in countries without statutory minimum wages to those with uniform statutory minimum wages and to those with youth-specific minimum wages. The concerning model that describes labor market outcomes is specified in a linear fashion:

$$
\begin{gathered}
y_{i j t}=\beta_{0}+\beta_{1} \text { UMWD }_{j t} \times I(i \leq 2)+\beta_{2} \mathrm{YWD}_{j t} \times I(i \leq 2)+\mathrm{AGE}_{i} \\
+ \text { COUNTRY_YEAR }_{j t}+u_{i j t}
\end{gathered}
$$

where, $y_{i j t}$ is the labor market outcome of interest-i.e., the employment rate, labor force participation rate, or the unemployment rate-for age category $i(i=1, . .4)$ in country $j(j=1, . ., J)$ in year $t(t=1, ., T)$. The variable $\mathrm{UMWD}_{j t}$ represents a dummy on 
uniform minimum wages, which assigns "1" to countries that have uniform minimum wages in year $t$ and " 0 " to countries without national minimum wage systems as well as to countries with youth minimum wages in year $t$. Likewise, $\mathrm{YWD}_{j t}$ represents a dummy that is equal to 1 if a country uses youth specific minimum wages in a particular year, and 0 otherwise. Our model also includes fixed effects for all possible combinations of countries and years. As such, we cannot estimate model parameters for the effect of (youth) minimum wages across all age categories.

The main coefficients in model (1) are $\beta_{1}$ and $\beta_{2}$. These parameters describe the impact of having a uniform minimum wage and a youth minimum wage on the first two age categories that consist of individuals of 15-20 years and 21-25 years of age, respectively. The parameter values can thus be interpreted as the relative labor market performance of young individuals in countries with uniform and youth minimum wages, as compared to the relative labor market performance of their peers in countries without statutory minimum wages. Finally, the error term $u_{i j t}$ is assumed to be identically and independently distributed. We can estimate model (1) with interacted country and year fixed effects, while allowing for clustering effects at the level of countries.

In the second model, we concentrate on the group of countries that employ a national minimum wage to estimate the effect of the level of youth minimum wages on the outcome variables. We thus compare the group of countries with specific youth rates (group 1A) with the group that implements uniform minimum wages (group 1B). Again, we exploit differences in relative outcome variables between young individuals who are affected by the policy of youth minimum wages and the relative outcome variables of their peers who are not exposed to lower rates. This yields the following model for labor market outcomes:

$$
\begin{gathered}
y_{i j t}=\beta_{0}+\beta_{1} \mathrm{YMD}_{i j t}+\beta_{2} \mathrm{YMW}_{i j t}+\mathrm{AGE}_{i}+ \\
\text { COUNTRY_YEAR } \\
j t+v_{i j t}
\end{gathered}
$$

where $y_{i j t}$ is the labor market outcome of interest for age category $i$ in country $j$ in year $t$. The variable $\mathrm{YD}_{i j t}$ represents the "youth minimum dummy," which assigns "1" to the relevant age categories that receive less than the adult minimum wages in those countries where lower youth rates exist, and "0" otherwise. The variable $\mathrm{YMW}_{i j t}$ is the youth rate expressed as a fraction of the adult minimum wage for the age categories for which the youth minimum applies; for those for whom the youth minimum does not apply, the value is normalized to " 1 ". By including $\mathrm{YMW}_{i j t}$, we can test whether the youth minimum wage effects are proportional to the relative level of youth minimum wage-that is, $\beta_{2}$ is the quasi-elasticity of youth minimum wages on the outcome measure of interest. As an alternative to the relative level of youth minimum wages as compared to the adult rate, we also present model outcomes with the youth minimum wage measured as a fraction of the median wage-i.e., the Kaitz index. Similar to Eq. (1), we also assume $v_{i j t}$ to be identically and independently distributed. We estimate the model with country and year fixed effects and allow for standard errors that are clustered across countries.

\section{Estimation results}

Table 2 summarizes the estimation results of Eq. (1) for the employment rate, labor force participation rate, and the unemployment rate as outcome measures. Since Eq. 
Table 2 Estimation results of model [1]; $N=1740$

\begin{tabular}{llll} 
& $\begin{array}{l}\text { Employment } \\
\text { rate }\end{array}$ & $\begin{array}{l}\text { Labor force participation } \\
\text { rate }\end{array}$ & $\begin{array}{l}\text { Unemployment } \\
\text { rate }\end{array}$ \\
\hline $\begin{array}{l}\text { Uniform minimum wage and age below } \\
25\end{array}$ & $\begin{array}{l}(3.80) \\
\text { Youth minimum wage and age below } 25\end{array}$ & $\begin{array}{l}-16.53^{* * *} \\
(4.14)\end{array}$ & $\begin{array}{l}5.62^{*} \\
(2.86)\end{array}$ \\
& -5.72 & -6.34 & 2.90 \\
Country-year & $(5.37)$ & $(5.98)$ & $(2.93)$ \\
Fixed effects (Number of FE: 300) & YES & YES & YES \\
Age dummies & & & \\
Intercept & YES & YES & YES \\
& $31.11^{* * *}$ & $37.66^{* * *}$ & 0.15 \\
$R^{2}$ & $(2.90)$ & $(3.12)$ & $(7.65)$ \\
\hline
\end{tabular}

Note: Standard errors, which are clustered at the level of countries, are shown in parentheses $* / * *$ indicate significance at the level of $10 \% / 1 \%$

(1) does not require specific information on the level of minimum wages and the minimum age of adult minimum wages (if relevant), we can estimate this model for all countries in our sample. Table 2 suggests that the relative performance of young individuals below the age of 25 in countries with a uniform minimum wage is worse than their peers in countries without statutory minimum wages (which is used as a reference group). More specifically, they are less likely to be employed and less likely to participate in the labor market, with negative effect estimates of about 14 percentage points and 16.5 percentage points, respectively. Interestingly, these negative effects of a minimum wage are insignificant when (lower) youth minimum wages apply. Individuals below the age of 25 for which a subminimum applies perform equally well with their peers in the group of countries with no legal minimum wages (as compared to individuals older than 25).

In line with Dolton and Bondibene (2012), these findings indicate that a uniform minimum wage across all ages may provide an incentive to employers to cut down employment of young individuals. Moreover, the results could be explained by the existence of discouraged-worker effects; youths who expect that finding a job will be difficult because of the existence of a binding minimum wage are more likely to withdraw from the labor market, typically by prolonging their time in education.

Next, we focus on the group of countries with minimum wages-including both with youth rates (group 1A) and with uniform minimum wages (group 1B) and on individuals below the age of 35 . Table 3 reports the corresponding results, which are based on the estimation of Eq. (2) for the employment, labor force participation, and unemployment rates. For each of these outcome measures, we estimate a model specification that includes youth minimum wage dummies as well as a model specification with both youth minimum wage dummies and proxies for the relative level of youth minimum wages, i.e., the youth-to-adult minimum wage and the youth-to-median wage ratios-see columns (ii), (iii) and (iv).

Again, the outcomes of model specifications with only the youth minimum wage dummy reveal that young individuals in countries with youth minimum wages generally exhibit better labor market outcomes than those in countries that employ uniform minimum wages. When including the youth-to-adult minimum wage rate 


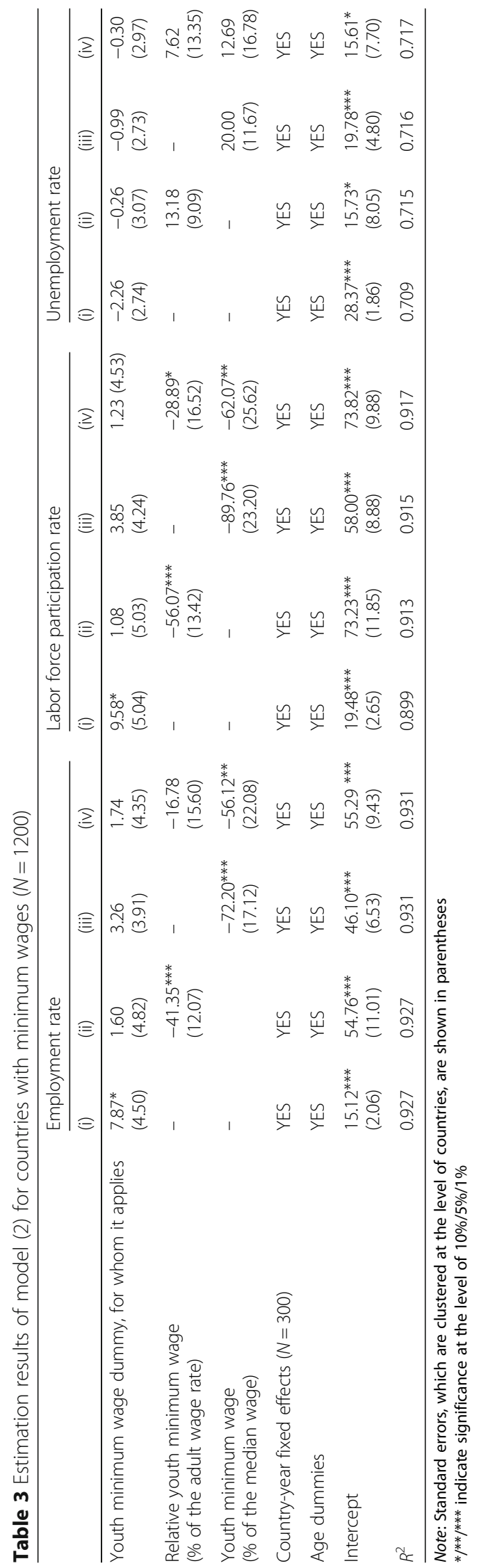


or the youth-to-median minimum wage rates, however, these dummy effects turn insignificant. This suggests that employment and labor force participation effects are proportional to both of these measures. From the coefficient estimate of the youth-to-median rate, we infer that the employment rate of young individuals decreases by 7.2 percentage points if the youth-to-median rate would increase with 10 percentage points. These coefficient effects are considerably bigger than those obtained by Dolton and Bondibene (2012), but comparable to those by Laporsek (2013).

From the estimates of the model specifications that include both youth minimum wage fractions, the picture that emerges is that the Kaitz index does a better job in explaining employment rate effects than the youth-to-adult minimum wage rate. Given that the average youth-to-adult minimum wage rate is 0.81 for whom it applies in our sample, a 10 percentage point increase in the youth-to-median rate corresponds to a 12.3 percentage point increase in the youth-to-adult rate. Based on our findings, the employment rate of young individuals would decrease by 5.6 percentage point due to the raise vis-à-vis the median wage and another 2.0 percentage point due to the raise vis-à-vis the adult minimum. ${ }^{9}$ Stated differently, the impact of a raise of the youth minimum wage would be 5.6 percentage points if adult minimum wages would be increased proportionally.

\section{Conclusions}

This study employs cross-national data from 30 OECD countries and for the time period 2000-2014 in order to explore the effect of introducing lower wages for young individuals on their labor market performance. Essentially, the identification follows from comparing the relative performance of individuals eligible for youth minimum wages with their peers in countries where this policy does not apply. Our results indicate that both the relative employment and labor force participation rates of individuals below the age of 25 are about 10 and 12 percentage points higher, respectively, in countries with youth minimum wages, as compared to countries with uniform minimum wages. Moreover, the effects are found to be proportional to the level of the youth wage, with an impact of an increase of the youth-to-median minimum wage of 1 percentage point that is equal to a decrease in the employment rate of 0.72 percentage point.

In line with earlier research, our results point at employment effects of minimum wages that are relatively large for younger individuals. Still, the effects we find are also considerably larger than those obtained from cross-country analyses that have been conducted by Neumark and Wascher (2004) and Dolton and Bondibene (2012). One explanation for this may be that our analysis is the first to use the exact level of youth minimum wages to explain the employment rates of younger individuals, rather than general minimum wages that are only a crude measure to detect minimum wage effects for young individuals. Accordingly, our estimates are less susceptive to attenuation bias. Related to this argument, it is important to stress once more that our research strategy exploits variation between age groups within countries and years to estimate youth minimum wage effects. By comparing young individuals below and above the age cutoff that gives eligibility to adult 
minimum wages, we are able to detect displacement effects that would have been left unnoticed if one would exploit variation between countries instead.

That being said, there might be room for improving the estimation youth minimum wage effects in some ways. Even though our data are the first to exploit country-level data on statutory youth minimum wage settings, there still might be variation in non-statutory or local settings that cause measurement error. In line with this, more detailed analyses that incorporate other institutional settings may help in deepening our understanding of minimum wage systems and their effect on youth labor markets. This particularly applies to labor standards, the design of education systems, opportunities for part-time work, union coverage, and employment protection legislation. All these institutions may affect the extent to which individuals and employers respond to minimum wage settings. Finally, for policymakers, it is of key importance to compare the employment effects of youth minimum wages with the income effects due to lower wage earnings for younger employed individuals.

\section{Endnotes}

${ }^{1}$ An exception to this is Card and Krueger (1994), who do not find employment effects for young workers. Consecutive research largely challenged their findings-see, e.g., Burkhauser et al. (2000) and Neumark and Wascher (2000).

${ }^{2}$ Following standard definitions, the labor force includes all individuals that are classified either as employed or unemployed. The labor force participation rate is defined as the share of labor supply of the total population between 15 and 65 years of age; unemployment and employment rates as expressed as shares of the labor supply.

${ }^{3}$ As we lack information on (youth) minimum wages for Chile, Israel, Mexico, and Slovenia, these countries are excluded from the sample.

${ }^{4}$ Table 6 in Appendix 2 provides a detailed overview of the sources on youth minimum wage systems.

${ }^{5}$ Note that some of these countries-including the USA, Japan, and Canada-have minimum wage settings that vary across localities. We argue that measurement problems stemming from this are probably limited if we relate youth to adult minimum wages, as this yields fractions that are less prone to measurement errors. In countries with uniform minimum wages, measurement errors will even be zero. Irrespective of the exact level of minimum wages, the young-to-adult minimum will then be equal to one in all localities.

${ }^{6}$ For instance, suppose the adult minimum wage applies to individuals of 22 and older. For the interval between 20 up to and including 24, we then have relative weights that are equal to 40 and $60 \%$, respectively.

${ }^{7}$ Note that Germany has adopted a statutory national minimum wage policy since 2015.

${ }^{8}$ Tables 4 and 5 in Appendix 1 provide more detailed information on the employment rates, labor force participation rates, and unemployment rates of countries.

${ }^{9}$ The coefficient estimate of the youth-to-adult minimum wage on the employment rate is -0.16 . Thus, the isolated impact of a youth minimum wage raise is $12.3 \times-0.16=-2.0$ percentage point. 


\section{Appendix 1}

Table 4 Labor market performance variables, 15-64 age of population for selected years (2000, 2010, and 2014)

\begin{tabular}{|c|c|c|c|c|c|c|c|c|c|}
\hline \multirow[t]{2}{*}{ Countries } & \multicolumn{3}{|c|}{ Employment rate } & \multicolumn{3}{|c|}{ Labor force participation rate } & \multicolumn{3}{|c|}{ Unemployment rate } \\
\hline & 2000 & 2010 & 2014 & 2000 & 2010 & 2014 & 2000 & 2010 & 2014 \\
\hline \multicolumn{10}{|l|}{ Group 1} \\
\hline Australia & 67.1 & 71.7 & 70.9 & 71.6 & 75.7 & 75.6 & 6.4 & 5.6 & 6.6 \\
\hline Belgium & 57.3 & 60.3 & 60.2 & 61.7 & 66.0 & 66.0 & 8.4 & 10.9 & 11.1 \\
\hline Canada & 68.4 & 70.7 & 71.6 & 73.5 & 77.0 & 77.1 & 7.2 & 8.7 & 7.6 \\
\hline Czech Repub. & 62.9 & 63.5 & 66.0 & 68.9 & 68.6 & 70.5 & 10.5 & 10.6 & 9.4 \\
\hline Estonia & 60.3 & 60.3 & 67.3 & 70.7 & 72.6 & 72.8 & 16.2 & 20.8 & 9.2 \\
\hline France & 58.7 & 62.9 & 63.3 & 65.4 & 69.5 & 70.4 & 11.3 & 11.1 & 12.1 \\
\hline Greece & 55.7 & 56.2 & 46.6 & 62.7 & 64.8 & 64.4 & 12.7 & 15.5 & 30.4 \\
\hline Hungary & 54.0 & 53.3 & 60.0 & 57.7 & 60.2 & 65.2 & 7.5 & 14.6 & 11.2 \\
\hline Ireland & 63.9 & 58.5 & 59.3 & 66.9 & 67.8 & 67.7 & 4.7 & 15.7 & 14.6 \\
\hline Japan & 67.7 & 68.7 & 71.1 & 71.3 & 72.6 & 74.0 & 5.7 & 5.8 & 4.0 \\
\hline Korea & 61.1 & 61.2 & 63.4 & 64.0 & 63.8 & 65.9 & 5.4 & 4.9 & 4.6 \\
\hline Luxembourg & 58.2 & 61.2 & 62.5 & 59.7 & 64.1 & 66.7 & 2.8 & 6.1 & 8.5 \\
\hline Netherlands & 69.0 & 74.2 & 72.7 & 71.3 & 77.8 & 78.6 & 3.2 & 4.8 & 7.9 \\
\hline New Zealand & 69.1 & 72.4 & 74.5 & 73.6 & 77.5 & 79.1 & 6.5 & 7.4 & 6.6 \\
\hline Poland & 53.1 & 58.0 & 60.1 & 63.2 & 64.2 & 66.3 & 17.5 & 11.5 & 11.9 \\
\hline Portugal & 67.2 & 62.7 & 60.2 & 70.1 & 71.0 & 70.9 & 4.6 & 13.6 & 18.5 \\
\hline Slovak Repub. & 54.5 & 57.1 & 58.9 & 66.5 & 66.6 & 67.9 & 20.8 & 18.4 & 17.4 \\
\hline Spain & 54.7 & 55.4 & 52.2 & 63.4 & 69.9 & 70.4 & 14.4 & 23.5 & 29.6 \\
\hline Turkey & 48.1 & 44.7 & 47.9 & 50.9 & 50.5 & 53.1 & 5.7 & 11.4 & 9.8 \\
\hline UK & 70.2 & 68.9 & 70.9 & 74.5 & 75.1 & 76.0 & 6.0 & 9.0 & 7.5 \\
\hline USA & 71.9 & 65.6 & 67.2 & 75.0 & 72.8 & 71.8 & 4.4 & 10.7 & 7.1 \\
\hline Average & 61.6 & 62.3 & 63.2 & 66.8 & 69.0 & 70.0 & 8.7 & 11.5 & 11.7 \\
\hline \multicolumn{10}{|l|}{ Group 2} \\
\hline Austria & 65.2 & 68.4 & 68.9 & 67.7 & 72.1 & 73.1 & 4.0 & 5.1 & 5.9 \\
\hline Denmark & 74.2 & 72.9 & 72.3 & 77.9 & 79.1 & 77.6 & 4.6 & 7.9 & 7.2 \\
\hline Finland & 65.3 & 68.3 & 68.5 & 72.6 & 74.8 & 75.2 & 10.9 & 9.9 & 10.0 \\
\hline Germany & 64.6 & 69.0 & 71.9 & 70.2 & 74.5 & 75.9 & 8.1 & 7.6 & 5.5 \\
\hline Iceland & 84.8 & 78.6 & 82.0 & 86.8 & 85.2 & 86.5 & 2.4 & 8.0 & 5.4 \\
\hline Italy & 51.6 & 53.7 & 52.4 & 57.8 & 59.2 & 61.0 & 12.2 & 12.5 & 19.2 \\
\hline Norway & 75.6 & 74.9 & 74.8 & 78.5 & 77.8 & 77.6 & 4.1 & 4.1 & 3.9 \\
\hline Sweden & 71.9 & 72.3 & 74.1 & 76.6 & 79.2 & 80.7 & 7.0 & 10.6 & 10.1 \\
\hline Switzerland & 76.6 & 77.4 & 78.5 & 78.8 & 81.3 & 82.4 & 3.0 & 4.8 & 4.9 \\
\hline Average & 70.0 & 70.6 & 71.5 & 74.1 & 75.9 & 76.7 & 6.3 & 7.8 & 8.0 \\
\hline
\end{tabular}

Note: Group 1 includes countries with statutory, uniform minimum wages and group 2 includes countries without statutory minimum wages 
Table 5 Labor market performance variables, averages per group of countries and age category, 2000-2014

\begin{tabular}{|c|c|c|c|}
\hline Groups and age categories & Employment rate & Labor force participation rate & Unemployment rate \\
\hline \multicolumn{4}{|l|}{ Group 1} \\
\hline $15-19$ & 19.6 & 24.9 & 26.9 \\
\hline $20-24$ & 53.7 & 63.7 & 16.5 \\
\hline $25-29$ & 74.2 & 82.5 & 10.1 \\
\hline $30-34$ & 77.2 & 83.7 & 7.8 \\
\hline $35-39$ & 78.6 & 84.5 & 6.9 \\
\hline $40-44$ & 79.4 & 85.0 & 6.5 \\
\hline $45-49$ & 78.0 & 83.2 & 6.2 \\
\hline $50-54$ & 72.6 & 77.3 & 6.1 \\
\hline $55-59$ & 58.4 & 62.0 & 5.9 \\
\hline $60-64$ & 34.0 & 35.7 & 4.7 \\
\hline Average & 62.6 & 68.3 & 9.7 \\
\hline \multicolumn{4}{|l|}{ Group 2} \\
\hline $15-19$ & 36.0 & 42.4 & 18.2 \\
\hline $20-24$ & 63.7 & 71.7 & 11.7 \\
\hline $25-29$ & 76.8 & 83.0 & 7.7 \\
\hline $30-34$ & 82.2 & 87.2 & 5.7 \\
\hline $35-39$ & 84.4 & 88.6 & 4.8 \\
\hline $40-44$ & 85.2 & 89.1 & 4.4 \\
\hline $45-49$ & 84.5 & 88.1 & 4.2 \\
\hline $50-54$ & 81.1 & 84.7 & 4.2 \\
\hline $55-59$ & 70.8 & 74.3 & 4.7 \\
\hline $60-64$ & 44.0 & 45.8 & 4.0 \\
\hline Average & 70.9 & 75.5 & 7.0 \\
\hline \multicolumn{4}{|l|}{ Group 1A } \\
\hline $15-19$ & 24.9 & 31.0 & 25.7 \\
\hline $20-24$ & 55.6 & 65.4 & 16.0 \\
\hline $25-29$ & 74.7 & 82.7 & 9.8 \\
\hline $30-34$ & 77.6 & 83.8 & 7.5 \\
\hline $35-39$ & 78.3 & 83.8 & 6.5 \\
\hline $40-44$ & 78.5 & 83.6 & 6.1 \\
\hline $45-49$ & 77.0 & 81.6 & 5.7 \\
\hline $50-54$ & 71.4 & 75.6 & 5.6 \\
\hline $55-59$ & 57.6 & 60.8 & 5.3 \\
\hline $60-64$ & 34.5 & 36.0 & 4.2 \\
\hline Average & 63.0 & 68.4 & 9.2 \\
\hline \multicolumn{4}{|l|}{ Group 1B } \\
\hline 15-19 & 11.4 & 15.5 & 29.7 \\
\hline $20-24$ & 49.3 & 60.2 & 18.7 \\
\hline $25-29$ & 73.2 & 82.8 & 11.5 \\
\hline $30-34$ & 76.7 & 84.2 & 8.7 \\
\hline $35-39$ & 79.0 & 85.7 & 7.8 \\
\hline $40-44$ & 80.2 & 86.5 & 7.2 \\
\hline
\end{tabular}


Table 5 Labor market performance variables, averages per group of countries and age category, 2000-2014 (Continued)

\begin{tabular}{lccc}
\hline Groups and age categories & Employment rate & Labor force participation rate & Unemployment rate \\
\hline $45-49$ & 78.6 & 84.5 & 6.9 \\
$50-54$ & 72.9 & 78.2 & 6.8 \\
$55-59$ & 57.6 & 61.6 & 6.5 \\
$60-64$ & 31.5 & 33.2 & 5.1 \\
Average & 61.0 & 67.2 & 10.9 \\
\hline
\end{tabular}

\section{Appendix 2}

Table 6 Youth minimum wage systems for selected OECD countries

\begin{tabular}{|c|c|c|c|c|}
\hline Country & $\begin{array}{l}\text { Youth } \\
\text { minimum } \\
\text { wages }\end{array}$ & Youth rates & Sources/references & Remarks \\
\hline Australia & Yes & $\begin{array}{l}15: 36 \% \\
16: 47 \% \\
17: 57 \% \\
18: 68 \% \\
19: 82 \% \\
20: 97 \%\end{array}$ & $\begin{array}{l}\text { - Australian Government, Fair } \\
\text { Work Ombudsman }\end{array}$ & $\begin{array}{l}\text { Australia is a country that } \\
\text { implements multiple youth } \\
\text { rates across the time span } \\
\text { of our data. }\end{array}$ \\
\hline Belgium & Yes & $\begin{array}{l}<16: 70 \% \\
17: 76 \% \\
18: 82 \% \\
19: 88 \% \\
20: 94 \%\end{array}$ & $\begin{array}{l}\text { - National Labour Council of Belgium } \\
\text { - Plasman, R. (2010). EEO Review: } \\
\text { Youth Employment Measures } \\
\text { Belgium. Brussels: European } \\
\text { Employment Observatory. } \\
\text { - Cockx, B. (2013). Youth } \\
\text { Unemployment in Belgium: } \\
\text { Diagnosis and Key Remedies, } \\
\text { IZA Policy Paper No. } 66, \text { Bonn: } \\
\text { IZA. } \\
\text { - OECD. Economic Surveys: } \\
\text { Belgium } 2015 . \text { Paris: OECD } \\
\text { - ILO Legal Databases (Acts } \\
\text { CCT No } 43 \text { and No } 50 \text { that } \\
\text { define the youth rates for } \\
\text { workers below the age of } \\
21) \text { : } \\
\text { - Collective agreement No. } \\
43 \text { of } 2 \text { May } 1988 \text { concerning } \\
\text { the amendment and } \\
\text { consolidation of Collective } \\
\text { agreements No. } 21 \text { of } 15 \text { May } \\
1975 \text { and No. } 23 \text { of } 25 \text { July } \\
1975 \text { on the guaranteed } \\
\text { minimum wage as modified } \\
\text { to November } 1998 \\
\text { - Collective Agreement on } \\
\text { the Guaranteed Minimum } \\
\text { Wage for Workers Younger } \\
\text { Than } 21 \text { Years, Agreement } \\
\text { No. } 50 \text { of } 29 \text { November } 1991 .\end{array}$ & $\begin{array}{l}\text { The youth minimum wages in } \\
\text { Belgium were phased out during } \\
\text { the period 2013-2015. } \\
\text { Accordingly, Belgium appears in } \\
\text { the data as a country } \\
\text { that implements youth rates } \\
\text { until } 2012 \text {. }\end{array}$ \\
\hline Canada & No & & $\begin{array}{l}\text { - Government of Canada } \\
\text { - Shannon, M. (2011). The } \\
\text { Employment Effects of } \\
\text { Lower Minimum Wage } \\
\text { Rates for Young Workers: } \\
\text { Canadian Evidence, Industrial } \\
\text { Relations: A Journal of Economy } \\
\text { and Society, 50(4): 629-655. } \\
\text { - OECD Employment Outlook } 1998\end{array}$ & $\begin{array}{l}\text { Reduced rates in Canada were } \\
\text { abolished prior to our data. } \\
\text { The country is treated as a } \\
\text { country with no youth rate } \\
\text { implementation. }\end{array}$ \\
\hline
\end{tabular}


Table 6 Youth minimum wage systems for selected OECD countries (Continued)

\begin{tabular}{|c|c|c|c|c|}
\hline Country & $\begin{array}{l}\text { Youth } \\
\text { minimum } \\
\text { wages }\end{array}$ & Youth rates & Sources/references & Remarks \\
\hline Czech Republic & No & & $\begin{array}{l}\text { - OECD. Economic Survey: Czech } \\
\text { Republic 2014. Paris: OECD } \\
\text { - Pavel Janicko (2012). Youth } \\
\text { Employment in the Czech Republic. } \\
\text { Friedrich-Ebert Stiftung: Czech } \\
\text { Republic. }\end{array}$ & $\begin{array}{l}\text { The lower minimum wage rates } \\
\text { were not applied based on } \\
\text { discrimination grounds. Any lower } \\
\text { rates concern only those aged } \\
18-21 \text { and employed for the first } \\
\text { time, reaching the } 90 \% \text { of } \\
\text { minimum wage and for the first } \\
\text { six months of employment. Thus, } \\
\text { they are not taken into account in } \\
\text { our analysis. }\end{array}$ \\
\hline Estonia & No & & - Statistics Estonia & No reduced rates. \\
\hline France & No & & $\begin{array}{l}\text { - OECD Employment Outlook } 1998 \\
\text { - OECD Employment Outlook } 2015\end{array}$ & $\begin{array}{l}\text { Lower wages for young workers } \\
\text { in France is associated with job } \\
\text { tenure. For example, those with } \\
\text { up to } 6 \text { months experience and } \\
\text { aged below the age of } 17 \text { are } \\
\text { eligible to } 80 \% \text { of the adult } \\
\text { minimum wage. For this reason, } \\
\text { France is treated as a country } \\
\text { with no specific youth wages. }\end{array}$ \\
\hline Greece & Yes & $<25: 89 \%$ & 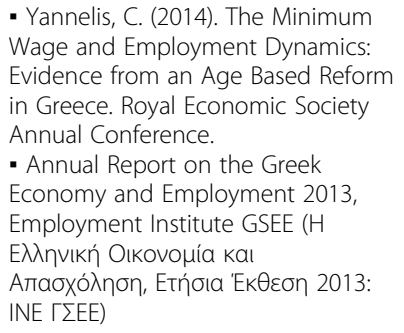 & $\begin{array}{l}\text { Greece introduced youth specific } \\
\text { minimum wages after } 2012 \text {. }\end{array}$ \\
\hline Hungary & No & & $\begin{array}{l}\text { - OECD Employment Outlook } 1998 \\
\text { - OECD Economic Surveys: Hungary } \\
2014\end{array}$ & $\begin{array}{l}\text { No reduced rates. OECD proposes } \\
\text { the introduction of lower rates to } \\
\text { fight high youth unemployment } \\
\text { and facilitate school-to-work } \\
\text { transition (OECD, 2014). }\end{array}$ \\
\hline Ireland & Yes & $<18: 70 \%$ & $\begin{array}{l}\text { - Citizens Information: Rights of } \\
\text { young workers } \\
\text { - OECD Employment Outlook } 2015\end{array}$ & $\begin{array}{l}\text { In case of Ireland, it is strictly } \\
\text { stated that "young people under } \\
\text { the age of } 18 \text { are only granted } \\
\text { up to } 70 \% \text { of the national } \\
\text { minimum wage". }\end{array}$ \\
\hline Japan & No & & $\begin{array}{l}\text { - OECD Economic Surveys: Japan } \\
2015 \\
\text { - OECD Employment Outlook } 1998 \\
\text { - OECD Employment Outlook } 2015\end{array}$ & $\begin{array}{l}\text { The regional minimum wages do } \\
\text { not appear to be a problem for } \\
\text { the analysis since there are no } \\
\text { specific youth wages to be } \\
\text { considered in this case. }\end{array}$ \\
\hline Korea & No & & $\begin{array}{l}\text { - Republic of Korea, Minimum Wage } \\
\text { Commission } \\
\text { - OECD Employment Outlook } 1998 \\
\text { - OECD Employment Outlook } 2015\end{array}$ & $\begin{array}{l}\text { Any lower rates are associated } \\
\text { with job tenure (for those up to } \\
6 \text { months of tenure and under } \\
\text { age of } 18 \text {, the rate is } 90 \% \text { ). Thus, } \\
\text { Korea is treated as a country that } \\
\text { does not use lower rates. }\end{array}$ \\
\hline Luxembourg & Yes & $\begin{array}{l}15-16: 75 \% \\
17: 80 \%\end{array}$ & $\begin{array}{l}\text { - The Official Portal of the Grand } \\
\text { Duchy of Luxembourg } \\
\text { - OECD Employment Outlook } 2015 \\
\text { - OECD Employment Outlook } 1998\end{array}$ & $\begin{array}{l}\text { Luxembourg has been } \\
\text { implementing lower youth rates } \\
\text { during the reference period. }\end{array}$ \\
\hline Netherlands & Yes & $\begin{array}{l}15: 30 \% \\
16: 34 \% \\
17: 39 \% \\
18: 45 \% \\
19: 52 \% \\
20: 61 \% \\
21: 72 \% \\
22: 85 \%\end{array}$ & $\begin{array}{l}\text { - Government of the Netherlands } \\
\text { - OECD Employment Outlook } 2015\end{array}$ & $\begin{array}{l}\text { The Netherlands has been using } \\
\text { multiple youth wage rates } \\
\text { throughout the time period } \\
\text { of our analysis. }\end{array}$ \\
\hline
\end{tabular}


Table 6 Youth minimum wage systems for selected OECD countries (Continued)

\begin{tabular}{|c|c|c|c|c|}
\hline Country & $\begin{array}{l}\text { Youth } \\
\text { minimum } \\
\text { wages }\end{array}$ & Youth rates & Sources/references & Remarks \\
\hline New Zealand & Yes & $\begin{array}{l}\text { Multiple } \\
\text { changes } \\
\text { over the } \\
\text { years }\end{array}$ & $\begin{array}{l}\text { - Employment New Zealand } \\
\text { - Hyslop, D. and Stillman, S. (2007). } \\
\text { Youth Minimum Wage Reform and } \\
\text { the Labour Market in New Zealand. } \\
\text { Labour Economics, 14(2): 201-230. } \\
\text { - Hyslop, D. and Stillman, S. (2011). } \\
\text { The Impact of the } 2008 \text { Youth } \\
\text { Minimum Wage Reform. } \\
\text { Unpublished, Labour and } \\
\text { Immigration Research Centre, New } \\
\text { Zealand }\end{array}$ & $\begin{array}{l}\text { During } 2001-2008 \text {, the adult } \\
\text { minimum wages applied to all } \\
\text { those above the age of } 18 \text {. From } \\
2008 \text {, the adult wage applies to } \\
\text { those above } 16 \text { years. From 2013, } \\
\text { the minimum starting-out wage } \\
\text { replaced the minimum wage for } \\
\text { new entrants and the training } \\
\text { minimum wage for trainees under } \\
20 \text { years of age. }\end{array}$ \\
\hline Poland & No & & $\begin{array}{l}\text { - OECD Economic Surveys: Poland } \\
2016 \\
\text { - OECD Employment Outlook } 1998\end{array}$ & No reduced rates. \\
\hline Portugal & Yes & $<18: 75 \%$ & $\begin{array}{l}\text { - OECD Employment Outlook } 1998 \\
\text { - OECD Employment Outlook } 2015\end{array}$ & $\begin{array}{l}\text { Lower wages for workers below } \\
\text { the age of } 18 \text { throughout the } \\
\text { reference period. }\end{array}$ \\
\hline Slovak Republic & Yes & $\begin{array}{l}<18: 80 \% \\
18-21: 90 \%\end{array}$ & - OECD Employment Outlook 2015 & $\begin{array}{l}\text { Lower wages for workers below } \\
\text { the age of } 21 .\end{array}$ \\
\hline Spain & No & & $\begin{array}{l}\text { - Blazquez et al. (2009), Minimum } \\
\text { Wage and Youth Employment Rates } \\
\text { in Spain: New Evidence for the } \\
\text { Period 2000-2008, Economic } \\
\text { Analysis Working Paper Series, } \\
\text { Autonomous University of Madrid. } \\
\text { - OECD Employment Outlook } 1998\end{array}$ & $\begin{array}{l}\text { No reduced rates. } \\
\text { Youth wages in Spain were } \\
\text { abandoned prior to the } \\
\text { beginning of the reference period } \\
\text { of our data. Before that, the lower } \\
\text { wages concerned those below } \\
\text { the age of } 18 \text { and amounted up } \\
\text { to } 89 \% \text { of the national wage. }\end{array}$ \\
\hline Turkey & Yes & $<16: 85 \%$ & - OECD Employment Outlook 1998 & $\begin{array}{l}\text { Turkey has introduced lower } \\
\text { wages for workers below the age } \\
\text { of } 16 \text {. }\end{array}$ \\
\hline UK & Yes & $\begin{array}{l}\text { Multiple } \\
\text { changes } \\
\text { over the } \\
\text { years }\end{array}$ & $\begin{array}{l}\text { - Gov.uk: National Minimum Wage } \\
\text { and National Living Wage Rates } \\
\text { - Dickens, R., Riley, R., and Wilkinson, } \\
\text { D. (2010). The Impact on } \\
\text { Employment of the Age Related } \\
\text { Increases in the National Minimum } \\
\text { Wage. Report prepared for the Low } \\
\text { Pay Commission. London: Low Pay } \\
\text { Commission. } \\
\text { - Dickens, R., Riley, R., and Wilkinson, } \\
\text { D. (2014). The UK Minimum Wage at } \\
22 \text { Years of Age: A Regression } \\
\text { Discontinuity Approach. Journal of } \\
\text { the Royal Statistical Society, 177(1): } \\
\text { 9-114. } \\
\text { - Fidrmuc, J. and Tena, J. d. D (2013). } \\
\text { National Minimum Wage and } \\
\text { Employment of Young Workers in } \\
\text { the UK." CESifo Working Paper, No. } \\
4286 .\end{array}$ & $\begin{array}{l}\text { UK has implemented various } \\
\text { youth rates across the years. } \\
\text { Using the governmental source, } \\
\text { we have captured all these } \\
\text { changes across age categories } \\
\text { and years. }\end{array}$ \\
\hline USA & Yes & $<20: 58 \%$ & - OECD Employment Outlook 2015 & $\begin{array}{l}\text { The lower wage for young } \\
\text { workers in the USA is associated } \\
\text { with job tenure. Analysis is } \\
\text { repeated with and without the } \\
\text { US data and the results are } \\
\text { robust. }\end{array}$ \\
\hline
\end{tabular}




\section{Acknowledgements}

The authors would also like to thank Stefan Hochguertel and the anonymous referees and the editor for the useful remarks to an earlier version of this paper.

Responsible editor: Denis Fougère.

\section{Competing interests}

The IZA Journal of Labor Policy is committed to the IZA Guiding Principles of Research Integrity. The authors declare that they have observed these principles.

\section{Publisher's Note}

Springer Nature remains neutral with regard to jurisdictional claims in published maps and institutional affiliations.

\section{Author details}

${ }^{1}$ Geneva School of Business Administration, Rue De La Tambourine 17, 1227 Carouge, Switzerland. ${ }^{2}$ Department of Economics, VU University Amsterdam, De Boelelaan 1105, P.O. BOX 80510, NL 1081 HV Amsterdam, The Netherlands. ${ }^{3}$ Leiden University, Leiden, The Netherlands. ${ }^{4}$ Tinbergen Instute, Amsterdam, The Netherlands. ${ }^{5}$ IZA, Bonn, Germany.

Received: 12 January 2018 Accepted: 1 February 2018

Published online: 29 March 2018

\section{References}

Burkhauser R, Couch K, Wittenburg DC (2000) A reassessment of the new economics of the minimum wage literature with monthly data from the current population survey. J Labor Econ 18(4):653-680

Carcillo S, Fernández R, Königs S, Minea A (2015) NEET Youth in the Aftermath of the Crisis, OECD Social, Employment and Migration Working Papers, No. 164, OECD Publishing, Paris

Card D, Krueger AB (1994) Minimum wages and employment: a case study of the fast-food industry in New Jersey and Pennsylvania. Am Econ Rev 84(5):772-793

Clemens J, Wither M (2016) The minimum wage and the great recession: evidence of effects on the employment and income trajectories of low-skilled workers, NBER working paper 20724, National Bureau of Economic Research

Dickens R, Riley R, Wilkinson D (2010) The impact on employment of the age related increases in the national minimum wage. Report prepared for the low pay commission. Low Pay Commission, London

Dickens R, Riley R, Wilkinson D (2014) The UK minimum wage at 22 years of age: a regression discontinuity approach. J R Stat Soc 177(1):9-114

Dolton P, Bondibene CR (2012) The international experience of minimum wages in an economic downturn. Econ Policy 27(69):99-142

Fidrmuc J, Tena JDD (2013) National minimum wage and employment of young workers in the UK. CESifo working paper, no. 4286

Hyslop D, Stillman S (2007) Youth minimum wage reform and the labour market in New Zealand. Labour Econ 14(2):201-230

Kalenkoski CM (2016) The effects of minimum wages on youth employment and income. IZA World of Labor 2016:243

Laporsek S (2013) Minimum wage effects on youth employment in the European Union. Appl Econ Lett 20(14):12881292

Neumark D, Salas JMI, Wascher W (2014) Revisiting the minimum wage-employment debate: throwing out the baby with the bathwater? Ind Labor Relat Rev 67(3):608-648

Neumark D, Wascher W (2000) Minimum wages and employment: a case study of the fast-food industry in New Jersey and Pennsylvania: comment. Am Econ Rev 90(5):1362-1396

Neumark D, Wascher W (2004) Minimum wages, labor market institutions and youth employment: a cross-national analysis. Ind Labor Relat Rev 57:223-248

Neumark D, Wascher W (2007) Minimum wages and employment. Foundations and Trends in Microeconomics $3(1-2): 1-186$

OECD (1998) OECD employment outlook 1998. OECD Publishing, Paris

OECD (2015) OECD employment outlook 2015. OECD Publishing, Paris

Olssen A (2011) The short run effects of age based youth minimum wages in Australia: a regression discontinuity approach. Paper presented at New Zealand Association of Economists Annual Conference, Wellington, 29 June-1 July 2011 